\title{
THE POSSIBILITY TO ENHANCE FLAVONOIDS PRODUCTION IN Rubia tinctorum L. CALLUS CULTURES
}

\author{
DANIELA KÁKONIOVÁ ${ }^{1}$, ŠTEFÁNIA VAVERKOVÁ \\ DESANA LIŠKOVÁ ${ }^{1}$, EVA URGEOVÁ ${ }^{3}$, ZUZANA JURÁKOVÁ ${ }^{1}$ \\ ${ }^{1}$ Institute of Chemistry Slovak Academy of Sciences, Dúbravská cesta 9, SK-845 38 \\ Bratislava, Slovak Republic (chemdaka@savba.sk) \\ ${ }^{2}$ Department of Botany and Pharmacognosy, Faculty of Pharmacy Comenius \\ University, Kalinčiakova 8, SK-832 32 Bratislava, Slovak Republic \\ (vaverkova@fpharm.uniba.sk) \\ ${ }^{3}$ Faculty of Natural Sciences, University of SS. Cyril and Methodius, Trnava, \\ Slovak Republic
}

\begin{abstract}
Production of flavonoids in madder callus culture (Rubia tinctorum L.) was dependent on culture conditions and culture media composition. The content of flavonoids increased in calli maintained on media supplemented with NAA (4 mg. $\left.1^{-1}\right)$ or NAA:BAP (4 mg. $\mathrm{l}^{-1}$ a $\left.1 \mathrm{mg} \cdot \mathrm{l}^{-1}\right)$ in $16 \mathrm{~h}$ photoperiod. Flavonoids represented $2.08-2.25 \%$ of callus dry mass. The presence of $\mathrm{Cd}\left(\mathrm{NO}_{3}\right)_{2}\left(3.1\right.$ or $31.0 \mathrm{mg} .1^{-1}$ concentrations) negatively influenced callus growth, but enhaced the percentage of dry mass in callus cells. During 42 days of culture an increase of cadmium accumulation and even of flavonoids has been observed. The most considerable influence of $\mathrm{CdCl}_{2}$ or $\mathrm{Cd}\left(\mathrm{NO}_{3}\right)_{2}$ on flavonoids content has been shown in short-term experiments after $48 \mathrm{~h}$ of callus culture. More distinct influence has been observed under the treatment with $\mathrm{CdCl}_{2}\left(0.005 \mathrm{mg} \cdot \mathrm{l}^{-1}\right)$ in comparison with $\mathrm{Cd}\left(\mathrm{NO}_{3}\right)_{2}$.
\end{abstract}

Key words: cadmium, callus, growth, madder, secondary metabolites

\section{Introduction}

The effort to use natural resources of vegetal and animal origin supports detailed investigation of familiar plant species for discovery of their still unknown impact against negative factors of the environment. Cultivation of medicinal plants is in the focus worldwide. This is evoked not only by the appearance of numerous civilization deseases, but also by the new look on prophylaxis and food health. Prominent plant species contain secondary metabolites usable in food industry, cosmetics, and mainly in pharmaceutical industry. Besides standard application and isolation of secondary compounds from natural resources, increasing significance win biotechnologies aimed on bioactive metabolites production and enhancement of their production abilities, predominantly plant cell cultures in vitro (PŠENÁKOVÁ et al., 2003; VANISREE and TSAY, 2004; VANISREE et al., 2004). Cell and callus cultures represent a continual renewable source of plant biomass and unlimited resource of desired pharmaceutical products.

Madder (Rubia tinctorum L.) is a medicinal plant (THURZOVÁ et al., 1983). Secondary compounds isolated from its root have diuretic effect and come in use by the treatment of kidney stones and as an auxilliary means in medication of rachitis and 
anaemia. This plant, coming from the south of Europe, was grown for red dye, alizarine. This drug contains also flavonoids, compounds with antioxidative effect. Commercial importance of flavonoids and a need for renewable resources of valuable chemicals has lead to attempts in developing alternative systems for their production. Different in vitro systems have been developed for flavonoids production, e.g., callus, cell suspension cultures, root and shoot cultures (JEDINÁK et al., 2004).

Biotic and abiotic elicitors can enhance secondary metabolites production. The stimuli are perceived by receptors activating secondary messengers. These transmit signals into the cell through signal transduction pathways leading to gene expression and biochemical changes (SUDHA and RAVISHANKAR, 2002) resulting in compounds formation. The basis for successful elicitation of secondary metabolites is the choice of suitable elicitor, its concentration, and optimal time of treatment. Many plant secondary metabolites are involved in the interaction of the plant with the environment. Increased contamination of the environment by toxic metals has negative consequence for all kinds of organisms, including higher plants. Toxic metals in high concentrations inhibit growth and development of plants and disturb or change their biochemical and physiological processes. Cadmium is one of common industrial pollutants, harmful to plants already at low concentrations (NEHNEVAJOVÁ, 2002; ŠUPALOVÁ, 2004).

The aim of this study was to detect the potential of madder (Rubia tinctorum L.) callus cultures to produce flavonoids in dependency on culture media composition, physical conditions, combination and concentration of growth regulators, and the effect of Cd-salts - $\mathrm{Cd}\left(\mathrm{NO}_{3}\right)_{2}$ and $\mathrm{CdCl}_{2}$.

\section{Material and methods}

\subsection{Cultivation of callus cultures}

Callus cultures of madder (Rubia tinctorum L.) belong to the Collection of in vitro cultures at the Institute of Chemistry SAS in Bratislava. Callus cultures were isolated from leaf segments of madder seedlings and cultured on modified MURASHIGESKOOG (MS) medium (1962) or on Z medium (ČIERNA et al., 1991) at $25 \pm 1{ }^{\circ} \mathrm{C}$, under $60 \%$ relative air humidity, $16 \mathrm{~h}$ photoperiod, irradiance of $45-60 \mu \mathrm{mol} \mathrm{m} \mathrm{m}^{-2} \cdot \mathrm{s}^{-1}$, or in the dark. The callus cultures were subcultured every four weeks.

\subsection{Growth parameters and statistics}

The growth dynamics $\left(\Delta \mathrm{RI}_{(\mathrm{j}+7)}=\mathrm{RI}_{(\mathrm{j}+7)}-\mathrm{RI}_{\mathrm{j}}, \mathrm{RI}=\Delta \mathrm{m} / \mathrm{m}_{0}, \Delta \mathrm{m}=\mathrm{m}-\mathrm{m}_{0}, \mathrm{~m}=\right.$ fresh mass, $\mathrm{m}_{0}=$ initial mass of inoculum, $\mathrm{j}=$ day of culture) was statistically evaluated by Student's $t$-test and ANOVA. In all experiments 10 samples were used. The experiments were repeated twice.

\subsection{Elicitation of flavonoids}

The possibility to increase the content of flavonoids has been examined on media supplemented with NAA:BAP in various ratios - 2:0, 2:1, 4:0, 4:1 (mg.1 $\left.{ }^{-1}\right)$ under $16 \mathrm{~h}$ 
photoperiod or in the dark, in the presence of cadmium salts: $\mathrm{Cd}\left(\mathrm{NO}_{3}\right)_{2}$ or $\mathrm{CdCl}_{2}$ in different concentrations $\left(0.005 \mathrm{mg} . \mathrm{l}^{-1}, 0.05 \mathrm{mg} . \mathrm{l}^{-1}, 0.5 \mathrm{mg} . \mathrm{l}^{-1}, 3.1 \mathrm{mg} . \mathrm{l}^{-1}\right.$, and $31.0 \mathrm{mg} . \mathrm{l}^{-}$ $\left.{ }^{1}\right)$ during a short-term culture $(24,48$, and 168 hours), during 42 days on MS solid media, or with liquid media on paper bridges.

\subsection{Determination of flavonoids content}

Flavonoids were determined colorimetrically from lyophilized dry mass. Callus cultures were collected during the cultivation period, lyophilized, homogenized, and pulverized. The drug was subsequently extracted with acetone, shaked with EtOAc and then the samples were evaluated at $425 \mathrm{~nm}$ on Spekol Carl Zeiss - Jena 2 by modified method of TƯMOVÁ and RUSKOVÁ (1998). The average content of flavonoids was calculated from standard curve of quercetin (Europ. Formulary 1).

\subsection{Determination of cadmium content}

The content of cadmium in madder cells was analysed at the Institute of Geology, Faculty of Natural Sciences, Comenius University in Bratislava, Bratislava, Slovakia by nuclear absorption spectrophotometry.

\section{Results and discussion}

Callus cultures of madder (Rubia tinctorum L.) isolated from leaf segments and cultivated on two different media (MS or Z) showed similarity in growth and growth dynamics (Fig. 1A, 1B).

The content of flavonoids in cells altered as an answer on growth hormones in culture media and light period ( $16 \mathrm{~h}$ photoperiod or in the dark). Their values oscilated between 1.65 and $2.25 \%$ of callus dry mass (Fig. 2). The highest values of flavonoids were determined in calli grown at $16 \mathrm{~h}$ photoperiod on media containing NAA:BAP in the ratio $4: 0$ or $4: 1\left(\mathrm{mg} . .^{-1}\right)$. In these cases flavonoids made up 2.08 up to $2.25 \%$ of dry mass (Fig. 2). Plant growth hormones represent important and in many cases essential compounds of culture media as for callus cultures growth, so for secondary metabolites production (SIATKA, 1998). Type and concentration of growth hormones are specific for every culture grown in vitro. Their mutual combinations are determined experimentally. The highest amounts of flavonoids in Bellis perennis $\mathrm{L}$. callus culture were determined on media supplemented with 2,4-D in 0.1 and $1 \mathrm{mg} . \mathrm{I}^{-1}$ concentration, or with IAA in $0.1 \mathrm{mg} .1^{-1}$, possibly also with NAA $\left(1 \mathrm{mg} \cdot \mathrm{l}^{-1}\right)$. Lower or higher concentrations of growth hormones reduced the production of flavonoids (SIATKA, 1998). The content of flavonoids in Rubia tinctorum L. callus cells depended on the photoperiod length and NAA concentration, and the combination with BAP in culture media. The highest values of flavonoids were detected in calli growing on media with NAA $\left(4 \mathrm{mg} . \mathrm{l}^{-1}\right)$ or when NAA $\left(4 \mathrm{mg} . \mathrm{l}^{-1}\right)$ was combined with BAP $\left(1 \mathrm{mg} . .^{-1}\right)$ and grown in $16 \mathrm{~h}$ photoperiod (Fig. 2).

It is known that some metals may positively affect the production of secondary metabolites (ZHENG and WU, 2004; RAI et al., 2005). Cadmium e.g. enhances the 
biosynthesis of ajmalicine in suspension cultures of Catharanthus roseus during 24 $48 \mathrm{~h}$ of cultivation (ZHENG and WU, 2004).
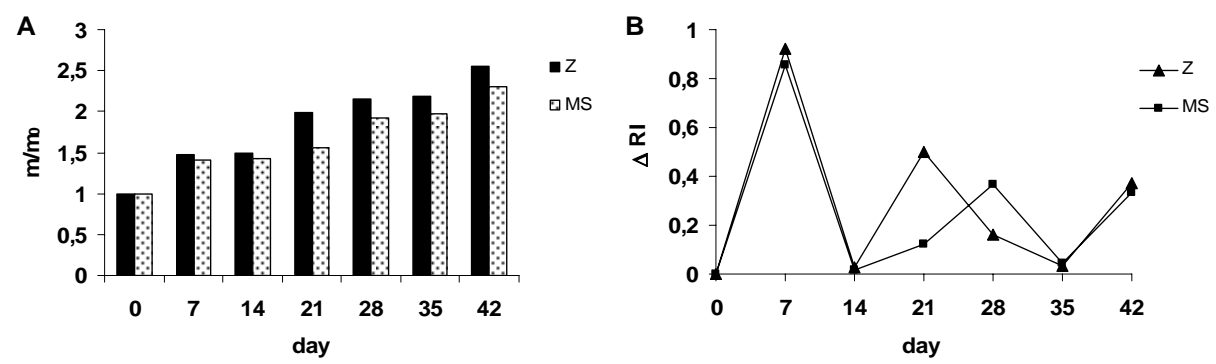

Fig. 1. Rubia tinctorum L. callus culture growth (A), growth dynamics of Rubia tinctorum L. callus culture (B).

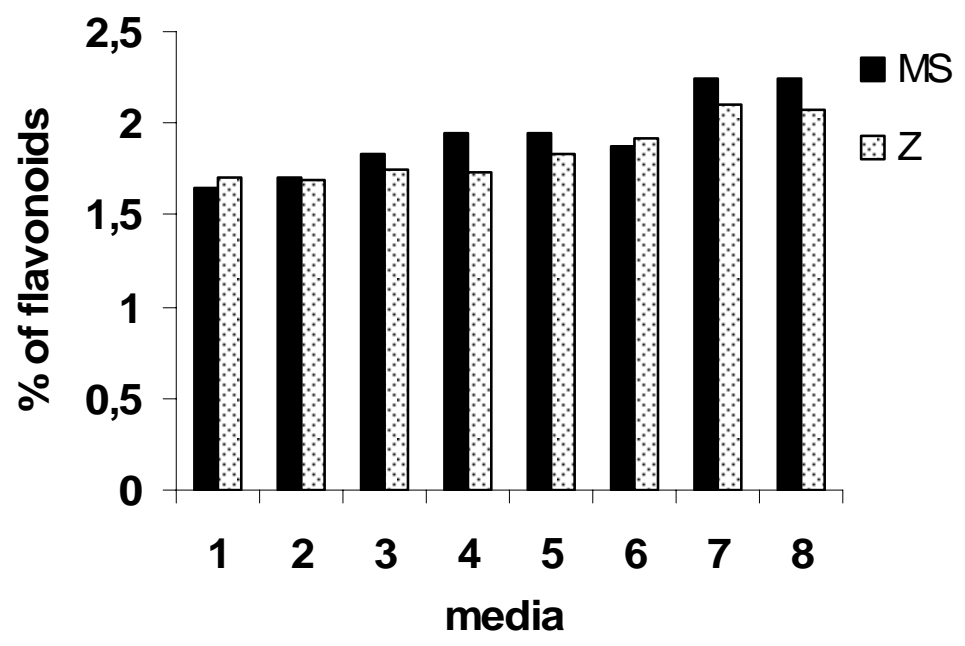

Fig. 2. Effect of MS and $\mathrm{Z}$ modified media and physical culture conditions ( $16 \mathrm{~h}$ photoperiod/dark) on flavonoids content in callus cultures of Rubia tinctorum L. NAA:BAP (mg. $\left.1^{-1}\right)$ - 1 - 2:0; 2 - 2:1; 3 - 4:0; 4 $4: 1$ - dark; $5-2: 0 ; \mathbf{6}-2: 1 ; \mathbf{7}-4: 0 ; \mathbf{8}-4: 1-16$ h photoperiod

Noticeable increase of rosmarinic acid in suspension cultures of Melissa officinalis L. was observed at the end of the second subculture (4 weeks of culture) by ŠUPALOVÁ (2004) when cultivated on media supplemented with $31.0 \mathrm{mg} . \mathrm{l}^{-1}$ $\mathrm{Cd}\left(\mathrm{NO}_{3}\right)_{2}$. In this case the content of rosmarinic acid was comparable with its content in intact plants. The presence of $\mathrm{Cd}\left(\mathrm{NO}_{3}\right)_{2}$ in 3.1 and $31.0 \mathrm{mg} .1^{-1}$ concentrations influenced negatively madder callus growth (Fig. 3A), but increased the $\%$ of dry mass after 42 days of culture (Fig. 3B).

The treatment of Phyllanthus amarus with a Cd-salt (higher than $50 \mathrm{ppm}$ and up to $100 \mathrm{ppm}$ ) significanly inhibited their growth. Decrease of dry mass, content of proteins, chlorophyll, and saccharides was evident. In contrast the content of starch 
increased, similarly as therapeutically active compounds - phyllantine and hypophyllantine (RAI et al., 2005). In madder cells cadmium accumulation corresponded with its concentration in culture media and duration of the treatment (Fig. 3C).
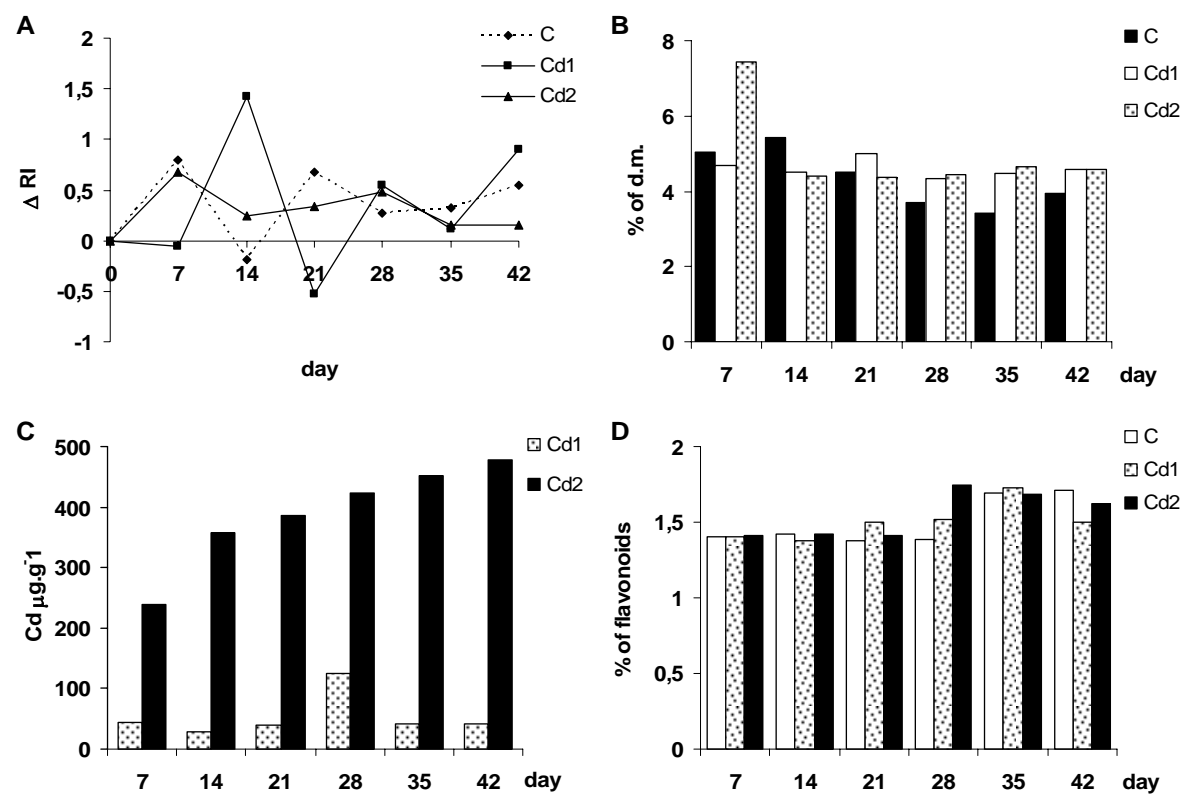

Fig. 3. Growth dynamics (A), percentage of dry mass (B), accumulation of cadmium (C) and content of

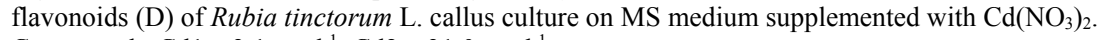

C - control; Cd1 - $3.1 \mathrm{mg} .1^{-1} ; \mathrm{Cd} 2-31.0 \mathrm{mg} . \mathrm{l}^{-1}$

These results are supported also by the findings of NEHNEVAJOVÁ (2002) in Ginkgo biloba L. callus culture. The highest concentration of $\mathrm{Cd}\left(\mathrm{NO}_{3}\right)_{2}$ during 4 subcultures enhanced the toxic effect of this salt on callus growth parameters, callus pigmentation, cells plasmolysis, and cell wall irregular thickenings. In madder callus, at the $31.0 \mathrm{mg} . \mathrm{l}^{-1} \mathrm{Cd}\left(\mathrm{NO}_{3}\right)_{2}$ concentration, the content of $\mathrm{Cd}$ increased already on the $7^{\text {th }}$ day of culture and this trend continued till the day 42 of culture on agar media (479 $\mu$ g. $\mathrm{g}^{-1}$ d.m.) (Fig. 3C). The production of flavonoids was time-shifted at both concentrations of the Cd-salt compared with the control. The presence of $3.1 \mathrm{mg} . \mathrm{l}^{-1}$ $\mathrm{Cd}\left(\mathrm{NO}_{3}\right)_{2}$ caused moderate stimulation already after 21 days with the maximum value on the $35^{\text {th }}$ day of culture. The highest values of flavonoids on media supplemented with the higher concentration $\left(31.0 \mathrm{mg} .1^{-1}\right)$ of $\mathrm{Cd}\left(\mathrm{NO}_{3}\right)_{2}$ on $28^{\text {th }}$ day were determined (Fig. 3D).

Production of flavonoids in madder callus cells cultured on paper bridges was positively affected by all concentrations of $\mathrm{CdCl}_{2}$ and $\mathrm{Cd}\left(\mathrm{NO}_{3}\right)_{2}$ tested, mainly after 24 and $48 \mathrm{~h}$ of culture. Most significantly was this process affected by the concentration $0.005 \mathrm{mg} . l^{-1}$ of $\mathrm{CdCl}_{2}$, when the content of flavonoids increased by $57-64 \%$ in comparison with the control (Fig. 4). 


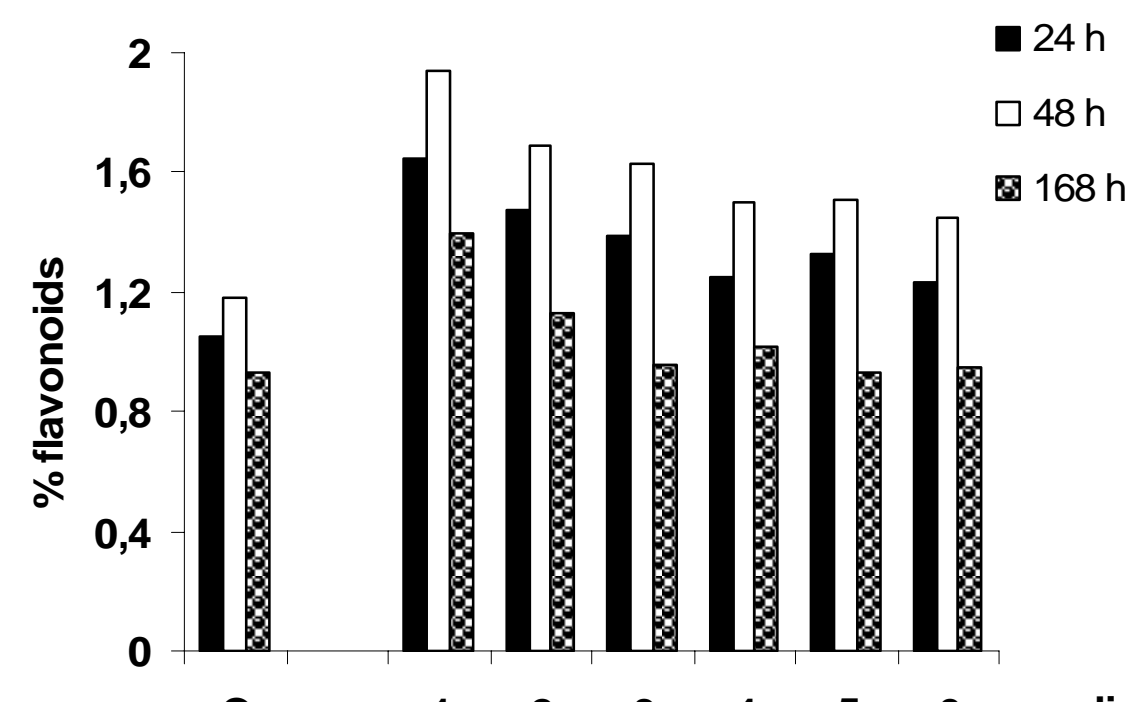

Fig. 4. Content of flavonoids in Rubia tinctorum L. callus cultures grown on paper bridges. C - control; $\mathbf{1}$ $\left.0.005 \mathrm{mg} . \mathrm{l}^{-1} \mathrm{CdCl}_{2} ; 2-0.05 \mathrm{mg} . \mathrm{l}^{-1} \mathrm{CdCl}_{2} ; 3-0.5 \mathrm{mg} . \mathrm{l}^{-1} \mathrm{CdCl}_{2} ; 4-0.005 \mathrm{mg} . \mathrm{l}^{-1} \mathrm{Cd}_{\left(\mathrm{NO}_{3}\right.}\right)_{2} ; \mathbf{5}-0.05 \mathrm{mg} . \mathrm{l}^{-1}$ $\mathrm{Cd}\left(\mathrm{NO}_{3}\right)_{2} ; 6-0.5$ mg..$^{-1} \mathrm{Cd}\left(\mathrm{NO}_{3}\right)_{2}$.

During this short-term culture no growth or uptake of Cd-salts by cells growing on paper bridges were observed. Very diminutive uptake was determined at the 0.005 mg. $l^{-1}$ concentration of $\mathrm{CdCl}_{2}$. This effect could be the result of ions interaction in liquid medium and of the short-term Cd-salt treatment. TƯMOVÁ and RUSKOVÁ (1998) have also ascertained a positive effect of $\mathrm{CdCl}_{2}$ as well as $\mathrm{CuSO}_{4}$ on the production of flavonoids in Ononis arvensis L. callus culture. They have observed that $\mathrm{CdCl}_{2}$ in $0.05 \mathrm{mg} . \mathrm{l}^{-1}$ or $0.5 \mathrm{mg} . \mathrm{l}^{-1}$ concentrations significantly increased flavonoids content after $48 \mathrm{~h}$, but the lowest concentration $\left(0.005 \mathrm{mg} . \mathrm{l}^{-1}\right)$ affected it already after $24 \mathrm{~h}$ of culture.

It can be concluded that plant growth hormones, and also Cd-salts (in suitable combination and concentration) in connection with physical conditions and length of the treatment, enhance the production of secondary metabolites in madder (Rubia tinctorum L.) cells cultured in vitro.

Acknowledgement: This work was supported by Slovak Grant Agency VEGA, grant No. 1/4354/07, APVV-COST -0004-06, and COST Action 859.

\section{References}

ČIERNA, M., KÁKONIOVÁ, D., LIŠKOVÁ, D.: A medium for rapid plant callus growth. Biologia, 46, 1991, 271-272.

EUROPEAN PHARMACOPOEA (Ph.Eur.) 4-nd. ed. Maissoneueve, France, 2000, 375-376 pp. 
JEDINÁK, A., FARAGÓ, J., PŠENÁKOVÁ, I., MALIAR, T.: Approaches to flavonoid production in plant tissue cultures. Biologia, 59, 2004, 697-710.

MURASHIGE, T., SKOOG, F.: A revised medium for rapid growth and bioassays with tobacco tissue cultures. Physiol. Plant., 15, 1962, 473-497.

NEHNEVAJOVÁ, E.: Effect of cadmium on growth parameters of Ginkgo biloba L., Thesis, Comenius University, Bratislava, 2002, 89 pp. [In Slovak]

PŠENÁKOVÁ, I., FARAGÓ, J., VAŠKOVÁ, L.: Application possibilities of in vitro plant systems for the production of secondary metabolites. Nova Biotechnol. III-2, 2003, 103-113. [In Slovak]

RAI, V., KHATOON, S., BISHT, S.S., MEHROTRA, S.: Effect of cadmium on growth, ultramorphology of leaf and secondary metabolites of Phyllanthus amarus Schum. and Thonn. Chemosphere, 61, 2005, 1644-1650.

SIATKA, T.: Effect of auxins on Bellis perennis L. callus cultures growth and flavonoids production. Čes. Slov. Farm., 47, 1998, 273-275. [In Czech]

SUDHA, G., RAVISHANKAR, G.A.: Involvement and interaction of various signaling compounds on the plant metabolic events during defense response, resistance to stress factors, formation of secondary metabolites and their molecular aspects. Plant Cell Tiss. Org. Cult., 71, 2002, 181-212.

ŠUPALOVÁ, A.: The influence of cadmium on growth parameters and content of rosmarinic acid in callus and suspension cultures of lemon balm (Melissa officinalis L.), Thesis, Comenius University, Bratislava, 2004, 113 pp. [In Slovak]

THURZOVÁ, L', KRESÁNEK, J., MAREČEK, Š., MIKA, K.: Small atlas of medicinal plants, Osveta, Bratislava, 1983, 324-325 pp. [In Slovak]

TƯMOVÁ, L., RUSKOVÁ, R.: Effect of $\mathrm{CdCl}_{2}$ and $\mathrm{CuSO}_{4}$ on flavonoids production in Ononis arvensis L. cultured in vitro. Čes. Slov. Farm., 47, 1998, 261-263. [In Czech]

VANISREE, M., TSAY, H.-S.: Plant cell cultures - an alternative and efficient source for the production of biologically important secondary metabolites. Int. J. Appl. Sci. Eng., 2, 2004, 29-48.

VANISREE, M., LEE, CH.-Y., LO, S.-F., NALAWADE, S.M., LIN, CH.Y, TSAY, H.-S.: Studies on the production of some important secondary metabolites. Bot. Bull. Acad. Sin., 45, 2004, 1-22.

ZHENG, Z.U., WU, M.: Cadmium treatment enhances the production of alkaloid secondary metabolites in Catharanthus roseus. Plant Sci., 166, 2004, 507-514. 